\title{
Erzurum Yerel Gazeteleri Örneğinde Yerel Haberciliğin Dijital Gazetelerde Uygulanışının Avantaj ve Dezavantajlarına Yönelik Bir Araştırma*
}

\section{A Study on the Advantages and Disadvantages of the Implementation of Local Journalism in Digital Newspapers in the Case of Local Newspapers of Erzurum}

\author{
Aslı Köseoğlu ${ }^{\text {a,** }}$ \\ a Arş. Gör., Atatürk Üniversitesi, İletişim Fakültesi, Gazetecilik Bölümü, 25240, Erzurum/Türkiye. \\ ORCID: 0000-0003-0180-7730
}

\section{MAKALE BILGGISİ}

Makale Geçmişi:

Başvuru tarihi: 06 Kasım 2017

Düzeltme tarihi: 02 Aralık 2017

Kabul tarihi: 07 Aralık 2017

\section{Anahtar Kelimeler:}

Yerel Habercilik

Haberde Yerellik

Dijital Gazetecilik

İnternet

Erzurum Yerel Basını

\section{ARTICLE INFO}

\section{Article history:}

Received 06 November 2017

Received in revised form 02 December 2017

Accepted 07 December 2017

\section{Keywords:}

Local Journalism

Localness on News

Digital Journalism

Internet

Local Press of Erzurum
ÖZ

Yerel basın bulunduğu coğrafyaya ilişkin haberler hazırlayarak; o bölgenin sorunlarını, ihtiyaçlarını, başarılarını bölge okuyucusuna ulaştıran; yönetenler ve halk arasında köprü görevi gören bir mecradır. Dijital teknolojide meydana gelen gelişmeler neticesinde yerel gazeteler de artık sayfalarını dijital ortama aktarmakta, gazeteler bu ortamın sunduğu olanaklar neticesinde coğrafi sınırlılıklar olmaksızın dünyanın çeşitli yerlerindeki okuyuculara ulaşabilmektedir. Bu çalışma ile yerel gazetelerin dijital ortamı kullanmalarıyla yerel haberciliğe sağlanan avantaj ve dezavantajlar Erzurum ilinde yayınlanan Pusula, Yenigün, Milletin Sesi, Güne Bakış adlı günlük gazeteler örnekleminde ele alınmıştır. Çalışma kapsamında gazetelerin dijital sayfalarına yerel haberciliğin dijital ortamda sürdürülüp sürdürülmediğine ilişkin 1- 10 Ağustos 2017 tarihinde içerik analizi uygulanmış, gazete yöneticileri ile konuya ilişkin olarak önceden hazırlanan sorular üzerinden mülakatlar gerçekleştirilmiştir.

\section{A B S T R A C T}

Preparing news on its location, local press is a field that transports problems, necessities and achievements of the region to the readers and serves as a bridge between local ruler and people. With the result of improvements on digital technology, local newspapers transfer their content on digital media by which newspapers reach global readers without geographical finiteness. In this study, ensured advantages and disadvantages to local journalism with the usage of digital media are mentioned with sample daily newspapers that are published in Erzurum named as Pusula, Yenigün, Milletin Sesi, and Güne Bakış. In the context of the study, content analysis is conducted on newspapers whether they maintain local journalism on their digital pages or not between 1-10 August 2017 and interviews are carried out with newspaper editors through preconditioned questions.

\section{Giriş}

Yerel basın bağlı bulunduğu bölgenin sorunlarını, ihtiyaçlarını, eksikliklerini yöneticilere ileten, yöneticilerin yaptığı hizmet ve faaliyetleri de halka duyuran demokrasinin oluşmasını ve sürdürülmesini sağlayan önemli bir platformdur. Yerel gazeteler halka ulaştırdığı haberlerle okuyucularının ufkunu açmakta, mevcut konulara ilişkin sağlıklı eleştirilerin gerçekleşmesine ortam hazırlayarak bölgeye ilişkin bilgilerin yayılmasına aracılık etmektedirler. Ayrıca okur ve yöneticiler arasında köprü kurulmasını sağlayan yerel gazeteler, bulundukları bölgenin sesi olduklarından, halkın sorunlarını en iyi şekilde bilen ve bunları kelimelere dökerek yetkililere ulaştırabilen

\footnotetext{
* Bu çalışma, 26-27 Ekim 2017 tarihlerinde Koçaeli’nde düzenlenen II. Uluslararası İletişim, Edebiyat Müzik ve Sanat Çalışmalarında Güncel Yaklaşımlar Kongresi'nde bildiri olarak sunulmuştur.

** Sorumlu yazar/Corresponding author.

e-posta: aslikoseoglu@ atauni.edu.tr
} 
mecralardır. Üzerlerine aldıkları bu görevleri icra ederken sınırlı bütçelerle ayakta kalmaya çalışan yerel gazeteler, yeni iletişim teknolojilerinin kendilerine sundukları imkânlardan yararlanarak dijital ortamda faaliyet göstermeye başlamış ve neredeyse ücretsiz olan bu ortamda daha fazla okuyucuya ulaşır hale gelmişlerdir.

İnternet teknolojisi ile ortadan kalkan coğrafi sınırlılıklar dijital gazeteler için avantaj olurken; hızlı haber yazma adına meydana gelen teyit, kaynağın güvensizliği gibi sorunlar gazetelerin saygınlığını azaltmaktadır. Yerel gazetelere ilişkin yapılan çalışmalar ağırlıklı olarak ekonomik sorunları ele alırken; bu çalışma, yerel gazetelerin dijital ortamda yayın sürecini inceleyerek, dijital ortamın kendilerine sundukları avantaj ve dezavantajları belirlemeye yönelik olarak gerçekleştirilmiştir. Bahsedilen tüm bu noktalardan hareketle dijital ortamın yerel basın için faydalarından ve zararlarından bahsetmek, bu doğrultuda gerçekleştirilmesi planlanan akademik çalışmalara 1şık tutabilmesi bakımından önemlidir.

Çalışmada yeni iletişim teknolojilerinin yerel habercilikte; yerel sınırları aşma, okuyucu kitlesini arttırma, teyit sorunu gibi konularda meydana getirdiği avantaj ve dezavantajların irdelenmesi amaçlanmıştır. Yapılan bu araştırmanın evrenini Erzurum'da günlük olarak yayınlanan Pusula, Yenigün, Milletin Sesi, Güne Bakış gazetelerinin dijital sayfaları oluşturmaktadır. Bu gazetelerin örneklem olarak seçilme nedeni, dijital sayfalarını düzenli olarak güncellemeleridir. Çalışmaya haftalık gazeteler, internet gazeteleri, internetten yayınlanan televizyon kanalları dâhil edilmemiştir. Çalışma basılı gazetelerdeki yerel habercilikten ziyade dijital ortamda yerel gazeteciliğin temsiline yönelik olduğundan sadece örneklem olarak seçilen basılı gazetelerin dijital sayfaları ele alınarak tespitler yapılmıştır.

1 Ağustos 2017- 10 Ağustos 2017 tarihleri arasında yukarıda isimleri yazılı 4 basılı gazetenin dijital sayfalarına içerik analizi uygulanmış, çalışma kapsamında gazetelerin yöneticileri ile dijital gazeteciliğin avantaj ve dezavantajlarına ilişkin olarak önceden hazırlanan sorular ile yüz yüze görüşme gerçekleştirilmiştir. Yenigün'ün yöneticileri çok yoğun oldukları gerekçesi ile görüşme talebini reddetmiş bu yüzden gazete sadece yerel haberciliğin değerlendirildiği kısımda çalışmaya dahil edilmiştir. Görüşme soruları açık uçlu olarak tasarlanmıştır. Zaman zaman görüşmeler esnasında belirlenen soruların dışına da çıkılarak konuya ilişkin veriler elde edilmiştir. Dijital gazeteler yukarıda belirtilen tarihler arasında incelenerek yerelliğin dijital ortamda okuyucuya ulaştırılması merkeze alınarak içeriklere ilişkin çeşitli kategoriler oluşturulmuştur.

\section{Bir İletişim Aracı Olarak Basıı Gazeteler}

Siyasi, sosyal, güncel konularda halkı bilgilendirmek, eğitmek adına çıkarılan günlük, haftalık ya da aylık olarak yayınlanan kitle iletişim araçları "gazete" olarak adlandırılmaktadır. Gazete kelimesi dilimize Latinceden Fransa aracılıyla geçmiştir. "Gazette" kelime anlamı olarak "haber bülteni" demektir. Batılı devletlerde "Journal" , "Diurna" (gündelik), "Chroincle" (haber sıralaması) adlarını almıştır (Karaduman, 2002: 13). Kökleri 14 yüzyıla kadar uzanan gazeteler, haber mektubu olarak kullanılmıştır. Gazetelerin yayınlanma nedeni savaş, göç gibi olayları duyurmaktır fakat zaman içerisinde bu kitle iletişim araçları propaganda yapmak, reklam yayınlamak, gelir elde etmek gibi amaçlara hizmet eder hale gelmişlerdir. Bugünkü anlamda ilk gazete 1609 yılında Strasbourg'da haftalık olarak Almanca yayınlanan Avisa, Relation oder Zeitun'dur. Daha sonra Hollanda'da Nieuwe Tijdinghe yayınlamıştır. (İnuğur, 2005: 57).

Osmanlı Devleti'nde yayınlanan ilk gazete 1795 yılında basılan ve Fransız Elçiliği tarafindan yayınlanan Bullettin Des Nouvelles'tir. Bu gazeteyi yine elçilik tarafından 1796 yılında yayınlanan Gazette Française de Constantinople takip etmiştir. La Spectateur Oriental (24 Mart 1824), İzmir'de 1824 'te çıkan La Smyrneen ve 1828'de çıkan Le Courrier de Smyrne, imparatorluğun gazete sicilineyer almaktadır. Mısır Valisi Kavalalı Mehmet Ali Paşa Kahire'de 1829 yılında Türkçe/Arapça olarak Vekay-i Mısrıye yayınlanmıştır. Padişah II. Mahmut'un emriyle 1831'de Fransizca olarak Le Moniteur Ottoman, yar1-resmi statüsüyle yayına başlamıştır. Osmanlı Devleti'ne gazete batıdan çok sonra gelmiş, ülke topraklarında yayınlanan ilk resmi gazete, II. Mahmut'un girişimleriyle 11 Kasım 1837 tarihinde yayınlanan Takvimi Vakayi olmuştur Daha sonra bu gazeteyi yarı resmi gazete kabul edilen Ceride-i Havadis Takip etmiş, ardından ilk özel gazete Şinasi ve Agah Efendi çıkarılmış, gazetenin adı Tercüman-ı Ahval olmuştur (Topuz, 1973: 5-10). İlerleyen yıllarda Tasvir-i Efkar, İkdam, Basiret, Muhbir, İbret, Sabah, Tanin gibi gazeteler basılmıştır. Gazetelerin sayısı her geçen gün artmış, gazeteler modernleşmenin sembolü haline gelmiştir. Gazetelerin yayınlanma amacı ağırlıklı olarak devletin gelişerek halkı gazeteler aracılığı ile eğitmesini sağlamak bu esnada halka her yönden değişmesini sağlamak olmuştur. Bugüne gelindiğinde ise gazeteler hala önemini korumakta, vatandaşları için bilgi edinme, öğrenme kaynağı olma görevini icra etmektedirler. Teknolojide yaşanılan gelişmeler neticesinde gazeteler sadece basılı olarak yayınlanmakla kalmamış, internet sayesinde dijital ortamda da erişilebilir hale gelmişlerdir.

\section{Yerel Basın}

Yerel basın, büyük şehirler dışında il, ilçe, belde hatta köylerde günlük, haftalık aylık olarak yayınlanan; yörenin haberlerini, sorunlarını isteklerini dile getiren; isteklerini yetkililere ileten mecradır. Girgin (2001: 160), yerel basının "Anadolu basını" ya da "Taşra basını" isimlerini de aldığını ifade ederek, yerel basının coğrafi sınırlılıklar içerisinde dar bir bölgede yaşayan halkı bilgilendirmeye, eğlendirmeye, eğitmeye, kamuoyu oluşturmaya çabalayan kitle iletişim araçları olduğuna vurgu yapmaktadır. Öztürk (1992: 152), yerel basının içerisinde yer aldığı toplumda birlik, beraberlik ve bütünleşmeyi sağlamayı hedeflediğini belirterek; bireyin toplumsal yapının bir parçası olduğunu hatırlatması gibi önemli bir işlevi olduğunu da dile getirmektedir. Ünal (1996: 1068)'a göre yerel basın, büyük yerleşim yerleri dışında kalan ilçe, bölge gibi belirli bir alanda yaşayan halkın ihtiyaçlarını, isteklerini, sorunlarını dile getiren; günlük, haftalık ya da aylık olarak yayınlanan basın organlarıdır.

Yerel gazete yayınlamak dünyada bir el sanatı olarak ortaya çıkmış (Stewenson, 2008: 89), zaman içerisinde meslek halini almıştır. Türk basın tarihi incelendiğinde gazetelerin ağırlıklı olarak yerel yayınlar yaptığı vurgulanmakta, gelişen teknoloji sayesinde bu gazetelerin yerel özelliklerini 
kaybederek ulusal hatta uluslararası yayınlanmaya başladı̆̆ belirtilmektedir. Bugün ulusal nitelik taşıyan çoğu gazete ancak 1960'lı yıllardan sonra İstanbul dışına dağıtılmaya başlamıştır (Girgin, 2001: 161).

Yerel basını yöre halkının kültürel ve sosyal gelişimine katkı sağlaması bakımından bir aynaya benzeten Gezgin (2007: 177), yerel gazetelerin toplumda yaşayan insanların sesi olduğuna dikkat çekerek, yerel basın sayesinde vatandaşların yaşadıkları şehre ilişkin gelişmeleri takip edebildiğini ve bu sayede demokratik ortamın oluşabildiğini ifade etmektedir. Yerel basın çalışanları ulusal basından farklı olarak; yöre halkını yakından tanımakta, bölgenin özelliklerini bilmektedir. Gezgin (2007: 177) yerel basının işlevini üç ana başlık altında toplamaktadır. Bunlar:

-"Yöneten-yönetilen ilişkisi çerçevesinde kamu hizmetlerinin sağlıklı ve doğru biçimde duyurulması yerel basının işlevlerinden biridir. Ayrıca, denetim, yönetenin halk adına denetlenmesi, kamuoyu yaratılması yerel basının üzerindeki sorumluluklardan biridir.

-Beldelerde yerel yönetimlerin hizmetlerinin duyurulmasıyla birlikte yerel yönetim-yurttaş ilişkisinin sağlanması yerel basının önemli işlevlerinden birisidir.

-Yaygın basının işlevlerinden biri olan eğitim işlevi; yerel basında toplumsal kimliği ile önem kazanır. Ulusal iradenin doğru ve amaca uygun yansımasında gerekli demokrasi kültürünün yerleştirilmesi, yerel basının en önemli işlevlerindendir."

Yerel basın ülke gelişimi bağlamında önemli bir konumdadır. Geneli ilgilendiren haberleri de barındıran yerel basın genel olarak dar bir bölgeye ilişkin haberler üretmekte böylece bölgenin gelişimine katkı sunmaktadır. Bireyler yaşadığı çevreye ilişkin sorun ve sorumlulukları bu mecra aracılığıyla öğrenerek, çevresine daha duyarlı bir hale gelmektedir (Gezgin, 2007: 178).

Yasama, yürütme ve yargıdan sonra dördüncü güç olan basın, yöneten ve yönetilenler arasında köprü işlevi görerek demokrasinin tabana yayılmasına aracılık etmektedir (Perin, 1974: 13).Yerel medya, vatandaşlara görüş bildirmeleri ve görüş almaları bağlamında demokratik çıkarımlar sunmaktadır (Habermas, 1984:4). Yerel basın, insanı gözeten bir yapının oluşmasında son derece etkili rol oynamaktadır (Güz, 1997: 22) İşlenen konu ve haberlerle çevresine duyarlı bireylerin yetiştirilmesini sağlayan yerel basın sayesinde bölgenin eksiklileri kısa sürede giderilmekte, sorunlar çözülmektedir. İster ulusal, ister bölgesel, ister yerel olsun; tüm basın mecralarının ilk görevi doğru ve tarafsı haberler üreterek, vatandaşları bilgilendirmektir. Yerel basın memleketinden uzakta yaşayan vatandaşlara "evinde olma hissi" yaşatması bakımından önemlidir. Yaşadığı şehirden ayrılan vatandaşlar bölgeye ilişkin haberleri yerel basın aracılığıyla takip ederek memleketine olan aidiyet duygularını sürdürmektedir.

\subsection{Erzurum Yerel Basını}

İlk yerel gazete olma özelliği taşıyan vilayet gazeteleri 1869 yılında Diyarbakır'da ve Erzurum'da yayınlanmaya başlamıştır (Gezgin, 2007: 108). Erzurum'un basın yayın hayatı Osmanlı Devleti'nde bu sürecin başladığı döneme denk düşmektedir. Tiflis’te gelişen Rus neşriyatına karşılık Doğu Anadolu'yu fikren aydınlatacak yayınlar yapılması amacıyla 1866'da Erzurum'da Envar-1 Şarkiye adıyla bir gazete çıkarılmıştır. Daha sonra Erzurum'un ilk özel gazetesi olan Hadikat-ül-Ahrar yayınlanmış, gazete halk tarafından büyük sevinçle karşılanmasına rağmen uzun ömürlü olamamış ve yaklaşık 5 ay sonra 20. Sayısını yayımlayarak yayın hayatına son vermiştir. Hadikat-ül-Ahrar gazetesinin ardından Bingöl, Saday-1 Şark, Farık, Mektep Duyguları ve Albayrak gazeteleri yayımlanmıştır. Tüm bu gazeteler Balkan harbi ve Birinci Cihan harbinden yorgun çıkıldığı halde milli mücadeleye hazırlanmak için çalışıldığı sıralarda yayınlanan gazetelerdir. $\mathrm{Bu}$ gazetelerin bütün amacı Mondros Mütarekesindeki çemberi kırmak ve Doğu Anadolu'nun Ermenilere verilmesine mani olmaktır (Alyanak, 1999: 38).

1928- 1946 tarihleri arasında şehirde yayınlanan gazeteler şunlardır: Özdilek (1923), Muallimler Birliği (1924), Bizim Gazete (1926), Türk Çocuğu (1926), Karyuvası Mecmuası (1927), Şen Yayla (1927), Yaylamız Erzurum (1934), Doğu (1936), Atayolu (1939), Erzurum (1939), Ajans Haberleri (1940), Erzurum (1943), Yayla (1944) ve Yeni Erzurum (1947) (Işı1k ve Eşitti, 2014: 55).

Demokrat Parti'nin iktidar olduğu dönem incelendiğinde Erzurum'daki gazetelerin genellikle hükümeti destekleyen yayınlar yaptığ 1 görülmüştür. Bu dönemde çıkan gazete ve dergiler; Demokrat Erzurum (1950), Doğu (1950), Pasinler (1950), Şarkın Sesi (1950), Demokrat Doğu (1951), Hâkimiyet (1951), Oltu (1951), Kale (1952), Şenkaya (1952), Yeni Çağ (1952), Aşkale Postası (1953), Demokrat Erzurum (1953), Gayret (1953), Sesimiz (1953), Yeni Aziziye (1953), Haber (1954), Horasan (1954), İnk1lap (1954), Palandöken (1954), Erzurum Ticaret Sicil Gazetesi (1955), Hürsöz (1955), Şark Postası (1955), Davamız (1956), Erzurum (1956), Hakikat (1956), Mefkûre (1956), Milletin Sesi (1956), Dadaş (1957), Doğu Ekspres (1957), Şafak (1957), Ufuk (1957), Demokrat Ilıca (1957), Karasu Kenarında (1958), Saksağan (1958), Aziziye (1959), Erzurum'un Sesi (1959), Serhat (1959), Tarih Yolunda Erzurum (1959) ve Yakutiye (1959)' dir (Işı1k ve Eşitti, 2014: 56-57).

1960 askeri müdahalesinden sonra Türkiye genelinde basıniktidar ilişkilerinin gerginleştiği görülmüş; bu durum Erzurum yerel basınında da değişiklik göstermemiştir (Şeker, 2007: 49). Bu dönemde Erzurum'da yayımlanan gazete ve dergiler; Çağlayan Aras (1960), Merhaba Gıdık (1960), Sabah (1960), Aşkale (1961), Hüryol (1961), Şalale (1962), Yeni Ümit (1963), Albayrak (1964), Enerji (1964), Hâkimiyet (1964), Hareket (1964), Hınıs'ın Sesi (1964), Pasinler'in Sesi (1964), Anadolu (1965), Çaba (1965), Devrim (1965), İmet (1965), Öğüt (1965), Yeni Şafak (1965), Aşkale'de Sabah (1966), Kahramanların Sesi (1966), Nene Hatun (1966), Uyanış (1966), Deneme (1967), Dadaş (1967), Kümbet (1967), Oltu (1967), Halkın Sesi (1968), Hamle (1968), Doğu İşin Sesi (1969), Kandilli’nin Sesi (1969), Adımlar (1970), Homongolos (1970), Yeşil İspir (1970), Çiftçinin Sesi (1971), Doğu'da Zirai Mü- cadele (1971), Erzurum Barosu Dergisi (1971), Hak Gör (1971), Dadaş (1973), Gurbet (1973), Erzurum Fuarı (1973), Oltu'nun Sesi (1973), Rehberlik Eğitimi (1973), Ilıca'nın Sesi (1974), Doğu (1976), Talebe (1976), Ülküdaş (1976), Yaylada Tarım (1976), Yağmur (1977), Büşra (1978), İntizar Teknizam (1978), Ülkü Ocakları (1978), Köy Dergisi (1979), Meşale (1979), Vahdet (1979), Yeni Aziziye (1979), 
Ferman (1980), Koz (1980) ve Türk Tuğrası (1980)'dır (Işık ve Eşitti, 2014:58).

1970'li yılların sonlarından itibaren gücü azalan yerel basının etkinliğini arttırmak için çeşitli çözüm önerileri geliştirilmeye çalışılmış ancak bir türlü zayıflamanın önüne geçilememiştir. Çözüm olarak Basın İlan Kurumu tarafindan 2010 yılı sonlarında teklif edilen benzer çizgide yayın yapan yerel gazetelerin birleşmelerinin teşvik edilerek nitelik ve etkinliğinin artırılması önerisi, 16 Ocak 2012 tarihinde Erzurum'da uygulamaya konulmuştur. Bunun neticesinde de o tarihte yayımlanmakta olan 16 gazete, yayın hayatına 4 gazete çatısı altında devam etmeye karar vermiştir (Işık ve Eşitti, 2014: 60). Gazeteler günümüz itibari ile Pusula, Yeni Gün, Milletin Sesi ve Güne Bakış’tır. Bu gazeteler günlük olarak yayınlanmaktadır.

\section{Yeni İletişim Teknolojilerinin Ürünü: Dijital Gazeteler}

20. yüzyılın sonlarına doğru gelişme gösteren internet, bilgiye ulaşma ve iletişim konularında başvurulan önemli bir alan haline gelmiştir. İnternet ortamında açılan haber servisi ve sayfaları bugün 'internet gazeteciliği', 'sanal gazetecilik', on-line gazetecilik' gibi adları almıştır (Toruk, 2008: 297298).

İnternet teknolojisinin gündelik hayata dâhil olmasiyla neredeyse tüm iş sektörleri dijital ortamı kullanır hale gelmiştir. İşte bu noktada dijital yerel gazeteler de internetin kendilerine sunduğu olanaklar neticesinde interaktif biçimde yayın yapmakta, zaman ve uzamın neredeyse tüm engellerini ortadan kaldırarak, aynı ya da farklı zamanlarda erişimi mümkün kılmaktadır (Dijk, 2016: 21-23). Ayrıca dijital gazeteler haber, metin, ses, içerik, video, grafik, animasyon, 360 derecelik video gibi imkânların tamamından yararlanabilme kapasitesine sahiptirler (Pavlik, 2013: 11).

İnternetin gündelik yaşama bu denli dâhil olmasıyla birlikte ortaya çıkan dijital gazeteler başlangıçta basılı gazetelerin birebir dijital ortama aktarılmıs hali iken artık bu ortam için özel haberler üretilmekte, hatta dijital gazetelerde yer alan haberlere ulaşabilmek için okuyucular aboneli sistemine dâhil olmaktadır. Çelik (2003: 3), hem yazılı basında hem de aynı anda sanal ortamda yayınlanan gazeteler olduğu gibi sadece sanal ortamda yayın yapan gazetelerin varlığına dikkat çekmektedir.

İlk olarak Amerika'da ortaya çıkan dijital gazete, Türkiye'de ilk kez 1995 yılında yayınlanan Aktüel Dergisi'dir. Zaman 1995 'te, Milliyet 1996'da, Hürriyet ve Sabah 1997'de online yayın hayatına başlamışlardır. Gazetenin tamamını online olarak veren ilk gazete Milliyet olmuştur. Bağımsız haber sitelerinin artması daha çok 2000 yılından itibaren nethaber, habertürk ve internethaber gibi siteler yayın hayatlarına başlamışlardır (Kara, 2012: 441-442).

"İnternet, geleneksel gazetecilik alanına, yeni ve farklı boyutların gelmesini sağlamıştır." Buradan anlaşılacağı gibi, internet enformasyonun hedef kitleye ulaştırılabileceği yeni bir alan olmuştur. Ancak internet kendine özgü olanaklarından dolayı, sadece mevcut kitle iletişim araçlarından çıkan enformasyonun yayılmasına olanak veren bir araç olmakla kalmamış, aynı zamanda enformasyonun yeniden üretildiği ve yeni biçimlerde sunulduğu bir ortam haline gelmiştir (Karaduman, 2005: 143).
Dijital gazetelerin basılı gazetelere göre çeşitli avantajları bulunmaktadır. Öncelikle dijital gazeteler haberi hızlıca yaymakta, okuyucunun farklı platformlarda aynı habere dair detaylı bilgi edinmesini sağlamaktadır. Kullanıcılar aynı anda habere dair hem fotoğraflara hem de videolara rahatlıkla ulaşabilmekte, çoklu ortamın nimetlerinden yararlanabilmektedirler. Okuyucular diledikleri yerden diledikleri habere ulaşabilmekte, dijital gazeteler sayesinde coğrafi sınırlar ortadan kalkmaktadır. Yaşanan değişimlerin temelinde internetin hizlı olması yatarken, bu ortamın okuyucu açısından yoruma açık olması ve anında geribildirim sunmas1, detaylara olanak sağlaması ve yayıncı ve tüketici bakımından özgürleştirici ortam sunması avantajlar arasında yer almaktadır (Dilmen, 2005: 96).

Kara'nın ifade ettiği gibi bu ortam maliyetleri düşürmüş ve okuyucuya neredeyse ücretsiz olarak hizmet sunmaktadır (Kara, 2005: 125-126). Dijital gazetelerde haberlerin arşivlerine ulaşmak da son derece kolaydır. Arşiv konusunda özgürlük sunan dijital gazeteler, verdikleri linkler ile okuyucuya konuya ilişkin farklı platformlar sunabilmektedir. (Gezgin, 2002: 31). Dijital gazeteciliğin dezavantajlarından ise şöyle bahsedilmektedir (Ayan'dan aktaran: Çakır, 2007):

“-Internet, büyük ve okuyan kesim için selüloz basın-silikon basın ayrımını yarattı. Gazeteye para veren kesimin büyük bir kısmı internetten haber takip edebileceği için para vermeyi bırakarak internetten takip etmeye başladı.

-Reklam verenler, gazete reklamcllarının verdiği ve karşı çıkılması zor reklamların ötesine geçip izlenebilir interaktif ortamın reklam gücünü görmeye başladı.

-Benzer içerik kendini onmaz bir biçimde göstermeye başladı. Özellikle bugünkü basın dünyasında Anadolu Ajansı gibi büyük ajansların haberleri çıkarıldı̆̆ında geriye bir şey kalmadığı açıkça görüldü. Özel haberlerin azlı̆̆ı göze çarptı. Küçük ücretlerle AA'dan haber alan internet siteleri, gazetelerle aynı sayıda ve kalitede haber üretmeye başladi.

-Haberlerde yepyeni bir "sürat faktörü" devreye girdi. Eskiden "haber atlatma” olarak tanımlanan kavram, gelen haberi çabuk yorumlayanlar, bir an önce internet ortamına hazır hale getirebilenler lehine çalışmaya başladı. Haberin özünü minimum detayla ilk veren, en çok tercih edilen basın organı olma yolunda önemli adımları attı.

-Genelde haber kaynaklarını sorgulama kavramı daha etkin biçimde devreye girdi.

-Gelişime ayak uyduramayan gazeteciler internet üstünde dolaşan esprileri anonim olarak alglayıp gazetesinin sütunlarında vermeye kalkınca komik durumlar çıktı: Bazı köşe yazarları, çalıştı̆̆ gazetenin köşe yazarlarının birkaç gün önce yazdı̆̆l yazıyı tekrar yayımlamaya kalkınca iş çı̆̆ırından çıktı.

-Gazete editör ve onay kadrosu, internet üstünden oluşturulmuş haberleri kontrol edemedi. Bu yüzden de gazetenin onay kadrosundan normal şartlarda asla geçemeyecek yanlışlıktaki haberler kendilerine hak etmedikleri kadar geniş yer buldu."

Dijital ortamda yayınlanan haberlerin objektifliği hakkında ciddi tartışmaların yaşandığı dünyada, gazeteci bu ortamda yazdığ1 haberin doğruluğunu sorgulamadan ve kanıtlamadan, tarafsız olduğunu iddia edebilmektedir. 
Esasında verilen hikâye ya da haber tarafsız olabilmekte fakat bu durum yazılan haberin doğru olacağ 1 anlamına gelmemektedir (Pavlik, 2013: 144). Aynı zamanda gazeteciler yaptıkları habere ilişkin linkler vererek haberi neren aldığına dair okuyucuya bilgi vermek zorundadır (Brayton, 2005'ten aktaran: Çoban, 2006: 43) günümüzde ise internet gazeteleri haber başka sitelerden alsalar dahi kaynak göstermeden kendi haberleri gibi lanse edebilmektedir. Hukuki düzenlemelerin eksik olduğu dijital ortamda, bu tür sorunlar henüz aşılamamaktadır.

\section{Dijital Gazetelerde Yerellik}

Vural (1999: 5), iletişim sürecinin elde bulunan imkânlar neticesinde başlangıçta yerel olarak gerçekleştiğine vurgu yaparken; Alankuş (2003: 6) da, iletişimin içerisinde bulunulan koşullar nedeniyle yerel olarak başladığına dikkat çekmektedir. Çünkü insanlar iletişim kurarken ilk olarak çevresinde olup bitenlere odaklanmakta, ilgi ve merak dalga dalga boyut değiştirmektedir. Hedef kitle ile kurulan coğrafi yakınlık (Şeker, 2007: 11) haberciliğin adeta vazgeçilmezlerindendir.

Haberlerin zaman ve mekân unsurlarından bağımsız düşünülememesi yerel haberciliğin mekânsal bağlamlarına gönderme yapmaktadır. Yerel kelimesi de genel olarak yerler, topluluk, şehirler, mahalleler ve mahalleleri birbirine bağlayan bölgeleri ifade etmek için kullanılmaktadır (Castells, 2000). Yerellik kelimesi ağırlıklı olarak bağlı bulunan coğrafyayı merkeze koyan tanımlamalar üzerinden yapılmaktadır. Yeni iletişim teknolojilerinin insanlara sunduğu olanaklar neticesinde coğrafi sinırlılık ve uzamlar sırasıyla ortadan kalkmış, yerel haberler küresel anlamda okuyucuya hizmet eder hale gelmişlerdir. Yerel haberler coğrafi sınırlamaların dişına çıkarak dünyada internetin olduğu her yere ulaş1labilir hale gelmiştir. Birçok düşünürün, gelişen teknoloji ile gündelik yaşamda önemli değişikliklerin meydana gelmesini beklediğini ifade eden Yolcu (2007: 435), genellikle maddi imkânsızlıklarla boğuşan medya kuruluşlarının yeni olanaklara kavuşacağını belirtmektedir.

Tablo 1: Ulusal ve Yerel Gazetelerin Tirajları

\begin{tabular}{ccc}
\hline \multirow{2}{*}{ Y1lar } & \multicolumn{2}{c}{ Gazeteler } \\
\cline { 2 - 3 } & Ulusal & Yerel \\
\hline 2012 Tiraj1 & 1.749 .219 .011 & 394.260 .858 \\
2013 Tiraj1 & 1.909 .495 .223 & 386.886 .781 \\
2014 Tiraj1 & 1.803 .467 .639 & 386.886 .781 \\
2015 Tiraj1 & 1.676 .001 .223 & 285.440 .701 \\
2016 Tiraj1 Toplam & \multicolumn{2}{c}{1.604 .000 .000} \\
\hline
\end{tabular}

Kaynak: (TUİK, 2017)

Tablo 1'den anlaşılacağı üzere; 2016 verileri incelenmiş, fakat Türkiye İstatistik Kurumu'nun gazeteleri yerel-ulusal olarak ayırmadan tirajı toplam sayı olarak verdiği görülmüş, bu yüzden 2016 yılının verilerine ayrı kategoriler açılmamış, gazete tiraj1 toplam olarak (yerel-ulusal bir arada) yazılmıştır. Ulusal gazetelerin tirajlarında dönem dönem dalgalanmalar görülürken, yerel gazetelerin tirajlarının her yıl düştüğü saptanmaktadır. Bunun başlıca nedeni insanların basılı gazeteler yerine dijital gazeteleri tercih eder hale gelmeleridir. Çünkü dijital yerel gazeteler internetin olduğu her yerden okunabilmekte, ücretsiz olarak okuyucuya haber sunmaktadır.
Dijital gazetelerin okuyucu kitleleri sınırlı değildir. Dünyanın herhangi bir yerinde meydana gelen olaya ilişkin bilgilere, okuyucu sadece bir "tık" sayesinde ulaşabilmekte ve konu hakkında fikir yürüterek habere dâhil olmaktadır. Coğrafi sınırları adeta yok eden dijital gazeteler sayesinde; yerel haberciliğe ilişkin zihinlerde var olan sınırlar ortadan kalkmış, okuyucular diledikleri yerden, diledikleri bölgeye ilişkin haberlere erişebilir hale gelmiştir.

\section{Calıșmanın Yöntemi}

Çalışmada görüşme ve içerik analizi tekniklerinden yararlanılmıştır. Görüşme, bir soru hakkında görüşülen kişilerden bilgi alma tekniği olarak adlandırılmaktadır. Diğer araştırma teknikleri içerisinde bu yöntem görüşme yapılan kişiye esneklik, derinlik gibi imkânlar sağlamaktadır (Aziz, 2014: 85). Görüşme lider yöneticilerle, uzmanlarla ve halkla olmak üzere üçe ayrılmaktadır (Karasar, 1991: 167). Bu çalışma kapsamında konuyla ilgili yöneticilerin görüşleri değerlendirmeye alınmıştır. Çalışmanın diğer amacı web sayfalarında yer alan yerel haberlerin sıklığını betimlemek olduğu için araştırmanın diğer yöntemi nitel araştırma yöntemlerinden biri olan içerik analizdir. Bir nitel araştırma yöntemi olan içerik analizi, bir metindeki değişkenleri ölçmek amacıyla, sistematik tarafsız ve sayısal olarak yapılan analizdir (Wimmer vd., 2000: 135-136). Çalışma, araştırma amaçlarına uygun tarama modeli kullanılarak yapılmıştır. Tarama modeli var olan mevcut bir durumu değiştirmeye kalkışmadan var olduğu biçimiyle betimlemeyi amaçlamaktadır (Karasar, 1991: 77).

\subsection{Yerel Haberlerin Gazetelerde Yer Alma Sıklığ 1 ve Haber Üretimi}

Çalışmada 1-10 Ağustos 2017 tarihleri arasında gazetelerin dijital sayfalarına web analizi yapılmış analizler neticesinde gazetelerde yayınlanan yerel, ulusal haberler aşağıdaki gibi kategorize edilmiştir.

Tablo 2. 1-10 Ağustos 2017 Tarihleri Arasında Gazetelerde Yayınlanan Yerel ve Ulusal Haber Sayılarına İlişkin Bilgiler

\begin{tabular}{lcc}
\hline Gazetenin Ad1 & Yerel Haber Sayıs1 & Ulusal Haber Sayı1 1 \\
\hline Pusula & 164 & 28 \\
Yenigün & 153 & 24 \\
Milletin Sesi & 148 & 19 \\
Günebakıș & 134 & 31
\end{tabular}

Yukarıdaki tablodan anlaşılacağı üzere araştırmanın yapıldı ̆̆ı tarihler arasında, dijital gazetelerde ağırlıklı olarak yerel haberler paylaşılmış; en fazla yerel haberi Pusula paylaşmıştır. Gazetelerinde ulusal haberlerden ziyade Erzurum'a ve çevre illere dair haberlere yer verdiklerini ifade eden Pusula Gazetesi Genel Yayın Yönetmeni Salih Tekin: “Erzurum Doğu Anadolu'nun adeta kalbi. Şehir her geçen gün daha gelişiyor. Şehre ilişkin sürekli haber akışımı mevcut çünkü her an her saniye yeni bir hizmet yeni bir yatırım geliyor bölgeye. Ulusal haberler zaten ulusal gazetelerde mevcut. Bizim habercilikteki asıl amacımız Erzurum ve civardaki şehirlerin halkını bilgilendirecek yerel haberler yapmaktır" (Tekin, 2017).

Dijital gazetelerinde genellikle habere ilişkin yerel fotoğraflar kullanmayı tercih ettiklerini ifade eden Milletin Sesi Gazetesi Haber Müdürü Muhammet Hanifi Aksakal: "Haberi en iyi anlatan malzeme haber fotoğrafidır. 
Haberlerimizde fotoğraf seçerken, o fotoğrafi kendi muhabirimizin çekmesini, çekilen fotoğrafin da konuyu anlatmasinı istiyoruz. Ulusala yanslyan haberlerde dahi konuyu anlatan yerel fotoğraflara başvuruyoruz, çünkü insanlar gazeteyi okumaya başladıklarında bildikleri, tecrübe ettikleri yer ve olaylarl gördügünde yerel gazete ile daha sıkı bağlar geliştiriyor, gazeteye güvenleri artıyor." demiştir (Aksakal, 2017).

Araştırma süreci boyunca gazetelerde toplam 599 yerel haber, 102 tane de ulusal haber yayınlanmıştır. Gazetelerde yayınlanan bu haberlerde kullanılan yerel görsellerin sayısı 614 olarak tespit edilmiştir. Buradan da anlaşılacağı üzere Erzurum dijital gazeteleri yerelliğe önem vermekte, bu doğrultuda haberler üretmekte ve haber fotoğrafları kullanmaktadır.

Tablo 3. 1-10 Ağustos 2017 Tarihlerinde Gazetelerde Yer Alan Haberlere Dair Veriler

\begin{tabular}{lccc}
\hline Gazetenin Adı & $\begin{array}{c}\text { Kendi } \\
\text { Muhabirlerinin } \\
\text { Haberleri }\end{array}$ & $\begin{array}{c}\text { Ajans } \\
\text { Haberleri }\end{array}$ & $\begin{array}{c}\text { Diğer (Haberi kimin } \\
\text { hazırladığına dair } \\
\text { bilgi yer almıyor) }\end{array}$ \\
\hline Pusula & 154 & 34 & 5 \\
Yeni Gün & 134 & 15 & 27 \\
Milletin Sesi & 119 & 38 & 10 \\
Güne Bakış & 123 & 24 & 18 \\
\hline
\end{tabular}

Yerel gazeteler sitelerinde çoğu zaman kendi muhabirlerinin haberlerine yer vermektedir. Yaşanılan şehre dair haber üretim sürecinde aktif rol oynayan yerel gazeteler zaman zaman ajans haberleri kullanmakta bazen de isimsiz haberler yayınlamaktadır. Pusula yöneticisi haber üretim aşamasında muhabirlerinin gözlemlerine güvendiklerini ifade ederek, fursat ve imkânlar dâhilinde her haber için olay yerine muhabir göndermeyi tercih ettiklerini, bu sayede gazete ile halk arasında bütünleşme sağlandığına dikkat çekmiştir.

Yerel halkın gazete muhabirini haberde görmesinin gazetelerinin saygınlığını arttırdığını ifade eden Güne Bakış Gazetesi Genel Yayı Yönetmeni ve Yazı İşleri Müdürü, ajans haberlerine ancak şehirde "son dakika" gelişmesi yaşandığında başvurduklarına dikkat çekmiştir (Akdağ, 2017). Görüşmelerde isimsiz yayınlanan haberlere dair somut gerekçeler sunulmamıştır.

Tablo 4. Gazetelerin Haber Kategorilerine İlişkin Bilgiler

\begin{tabular}{lccccc}
\hline Gazetenin Ad1 & Güncel & Eğitim & Sağlık & Spor & Siyaset \\
\hline Pusula & 108 & 10 & 18 & 32 & 13 \\
Yenigün & 83 & 16 & 31 & 23 & 21 \\
Milletin Sesi & 96 & 12 & 25 & 28 & 25 \\
Güne Bakış & 91 & 13 & 19 & 19 & 18 \\
\hline Toplam & 378 & 51 & 93 & 102 & 77 \\
\hline
\end{tabular}

Analizler esnasında haberlerin kategorileri; güncel, eğitim, sağlık, spor, siyaset olarak belirlenmiştir. En fazla haber paylaşımı 378 ile güncel haber kategorisinde yayınlanmıştır. Güncel haberin kapsamı Erzurum'da meydana gelen kazalar, belediyenin yaptığı hizmetler, vatandaşların istek ve şikâyetlerine yönelik olanlar olarak sınırlandırılmıştır. Sağlık haberleri ağırlıklı olarak ulusal haber olacak biçimde hazırlanmış bu haberlerde genel olarak besinlerin fayda ve zararları kaleme alınmıştır. Siyaset haberleri ülkenin genel siyaseti ile Erzurum'daki siyasi partilerin haberlerini kapsamaktadır. Araştırma boyunca 51 haber ile en az eğitim haberi paylaşıldığı tespit edilmiștir. Buna gerekçe olarak da Ağustos ayı içerisinde okulların tatil olması düşünülmüştür.

Yapılan incelemelerde gazetelere Cumartesi ve Pazar günleri daha az haber yüklendiği görülmüş; en fazla haberin Pazartesi günü yayınlandığı belirlenmiştir. Gazetelerin çalışanları hafta sonları tatil yaptığından, yapılan görüşmelerde Pazartesi günü gazetelerde iş yoğunluğu olduğu bulgusu elde edilmiş bu nedenle en fazla haberin haftanın ilk günü web sayfasına girildiği sonucuna ulaşılmıştır. Gazetelerin basılı ortam ile internette girdiği haberlerin karşılaştırması yapıldığında, internet gazetelerinin zaman ve mekân sınırlamalarından arındığı öne çıkmaktadır. Basılı gazeteler yayına koydukları haber sayıları ve gazetelerin dağıtıldığı bölge ile sinırlıyken bu noktada dijital gazetecilik avantajlı durumdadır. Çünkü internet ortamı istenilen haberin istenilen anda coğrafi sınırlamalar olmaksızın okuyucuya ulaştığı platformdur.

\subsection{Dijital Gazetelerin Yayınlanma Gerekçeleri ve $\mathrm{Bu}$ Gazetecilik Türünün Avantaj ve Dezavantajları}

Yeni Gün hariç diğer gazetelerin dijital ortama geçiş nedenleri yukarıdaki tabloda görülmektedir (Yeni Gün ile yoğunluk gerekçelerinden dolayı görüşme yapılamamıştır.) 3 gazete yöneticisi de okur sayılarını arttırmak, daha fazla tanınmak ve Basın İlan Kurumu'nun internet gazetesini zorunlu kılmasından dolayı dijital ortama geçtiğini ifade etmiştir. Gazeteler bu konuya ilişkin olarak hiçbir okur talebi almadıklarını dile getirmiş, sadece Milletin Sesi okurla etkileşim kurmayı amaçladıklarından dolayı bu platformu kullanmak istediklerine değinmiştir. Tablo incelendiğinde gazetelerin ekonomik nedenlerden dolayı bu ortamı kullanmadığı anlaşılmaktadır. Yapılan görüşmelerde dijital gazete yayınlama nedenlerinin Basın İlan Kurumu'nun bu ortamı kullanmalarını kendilerine zorunlu hale getirmesinden kaynaklandığını ifade eden yöneticiler, basılı gazetelerine kurumdan aldıkları resmi ilanları internet gazetelerinde de yayınladıklarını ifade etmişlerdir. İnternet gazetelerinde günlük yayınladıkları güncel haber, video haber sayılarına göre de kurumdan destek aldıklarını ifade eden yöneticiler, yine de internet gazeteciliğinin kendilerine kazandırmadığı (avantaj/fayda/yarar sağlamadığı) görüşünü savunmaktadır (Tekin vd., 2017).

Tablo 5. Dijital Gazetelerin Yayınlanma Nedenleri

\begin{tabular}{lcccc}
\hline Nedenler & Pusula & $\begin{array}{c}\text { Güne } \\
\text { Bakış }\end{array}$ & $\begin{array}{c}\text { Milletin } \\
\text { Sesi }\end{array}$ & Yün \\
\hline Okur Sayısını Arttırmak & + & + & + & \\
Okurla Etkileşim Sağlamak & - & - & + & \\
Ekonomik Gelir Elde Etmek & - & - & - & \\
Daha Fazla Tanınmak & + & + & + & \\
Basın İlan Kurumu'nun İsteği & + & + & + \\
İl Dışından Takip Edilmek & + & - & - & \\
Okuyucu Talebi & - & - & - &
\end{tabular}

Görüşülen yöneticiler coğrafi sınırların ortadan kalkmasının büyük bir nimet olduğuna vurgu yaparken, haberin hızlıca okura ulaşması bağlamında internet ortamının sağladığı avantaja yoğunlaşmış, hız unsurunun gazetecilikte çığır açtığını dile getirmişlerdir. Günebakış’ın yöneticisi dijital gazeteleri sayesinde okuyucuları ile kısa sürede etkileşim sağladıklarını ifade ederek: "Internet gazetesi sayesinde okurlarımı bizi her an her yerden takip edebilir hale geldiler. Web sitemize yüklediğimiz bir habere okurlardan 
kısa sürede yorumlar geliyor. Biz de bu yorumlarl dikkate alarak haber hakkında daha detaylı bilgiye ulaşmayı sağllyoruz." demiştir (Akdağ, 2017). Pusula yöneticisi muhabirlerinin ofise gelmeden dahi haberi oluşturarak haber merkezine ulaştırdığını ifade etmiş, dijital gazeteleri sayesinde de çok kısa sürede hazırlanan bu haberlerin okuyucularına ulaştığını dile getirmiştir (Tekin, 2017). Dijital gazeteciliğin habere ulaşmada zaman tasarrufu açısından kendilerine avantaj sağladığı ifade eden yöneticiler, kısa sürede birçok olaydan haberdar olduklarını dile getirmiş; bu haberlerinin okuyucuya ulaşma aşamasında internet gazetelerinin kendilerine kolaylık sağladığını belirtmişlerdir

Pusula yöneticisi, internet gazeteleri sayesinde sitelerine yükledikleri haberlerinin çok kısa bir zaman diliminde birçok yere ulaştığını belirterek: "Eskiden gazetemiz sadece Erzurum'daki okuyuculara ulaşıyordu. Internet sayesinde Azerbaycan'dan, Rusya'dan, Gürcistan'dan, Almanya'dan takipçilerimiz oluyor. Gazetede yer alan bir habere ilişkin bilgi almak için dünyanın çeşitli yerlerinden aranıyoruz, bu sayede daha fazla okura kısa sürede ulaşıyoruz." (Tekin, 2017). Konuya ilişkin olarak geçmiş dönemlerde İngilizce bir mail aldıklarını ifade eden yönetici, mailin Amerika'dan geldiğini ifade etmiş, mailde organlarını satmak isteyen bir vatandaşın fiyat tarifesini gazetelerinde yayınlayıp yayınlayamayacaklarını sorduğunu dile getirmiştir. Dijital gazetelerinin olmadığını düşündüklerinde Erzurum'da yayınlanan yerel bir gazetenin dünyanın öbür ucundan bilinmesinin hatta mektup almasının mümkün olmadığı dile getirmiştir (Tekin, 2017).

Tablo 6. Dijital Gazetelerin Maliyete Etkisi

\begin{tabular}{lccc}
\hline Gazete Ad 1 & Maliyet Arttı & Maliyet Azaldı & Etkisi yok \\
\hline Pusula & - & - & + \\
Milletin Sesi & - & - & + \\
Günebakış & - & - & + \\
\hline
\end{tabular}

Tablo 6'da dijital gazetelerin yayınlanmasının gazete maliyetini nasıl etkilediğine ilişkin görüşmelerden elde edilen veriler yer almaktadır. Dijital gazeteciliğin kendilerine maddi anlamda bir katkı sağlamadığına vurgu yapan yöneticiler, bu gazetecilik türünün ciddi bir masrafının olmadığını belirmişlerdir. Üç yönetici de dijital gazetenin, gazete maliyetlerine etkisinin olmadığ1 görüşünde buluşmuştur. (Tekin vd., 2017). Reklam ve ilanları ilan verenlerden gelen talepler üzerine genellikle basılı gazetelerinde yayınladıklarını ifade eden yöneticiler, dijital gazetelerinde basılı gazetelerde yer alan ilanları ve reklamları yayınladıklarını belirtmişlerdir.

Pusula yöneticisi, internet gazeteciliğinin basılı gazetelerin tirajlarını düşürdüğüne dikkat çekmiştir. İnsanların herhangi bir konuya ilişkin bilgi almak istediklerinde başvurdukları araçlardan biri olan basılı gazetelerin internet gazetelerinin ortaya çıkmasından dolayı eskiye göre daha az satın alındığının altını çizmiştir. Buna çözüm olarak da hazırladıkları özel haberleri basılı gazeteye hemen koymadıklarını ifade eden yönetici, internet gazetesinde özel haberin birkaç gün kaldığını bu sayede kamuoyu oluşturarak haberi okuyucunun merak etmesini sağladıklarını ifade etmiştir. Özel haberlerin internet gazetesinde yayınlandıktan bir iki sonra basılı gazetede yayınlandığına vurgu yapmıştır (Tekin, 2017). Basılı gazetelerin okunma sayısında her geçen gün düşüşün olduğunu ifade eden Milletin Sesi yöneticisi, bu düşüşe rağmen basılı gazeteye dokunmaktan haz duyan okuyucu kesiminin olduğuna vurgu yapmıştır. Yönetici, dijital gazete okuyucularının teknolojinin sunduğu olanaklar neticesinde artacağı kanısındadır (Aksakal, 2017). Pusula yöneticisi, kısa sürede güncelliğini yitiren haberler nedeniyle Türkiye gündemini takip etmekte zorlandıklarını ifade etmiştir (Tekin, 2017).

Hız unsuruyla birlikte hukuki sorunların ortaya çıktığına dikkat çeken Milletin Sesi yöneticisi: “Internet gazetemizi sürekli güncelliyoruz, sıkça özgün haberler sitemize yükleniyor. Muhabirimizin çeşitli uğraşlar sonucu oluşturduğu haberler bir başka sitede kaynak dahi gösterilmeden sanki o sitenin kendi haberiymiş gibi bizde yayınlandıktan beş dakika sonra başka bir haber sitesinde de okuyucu ile buluşturuluyor. Burada emeğin hiçe saylması söz konusu. Zaman zaman hukuki süreçler başlatsak da olumlu sonuç alamıyoruz. Dijital ortama ilişkin tam anlamıyla hukuki düzenlemenin olmaması bizlere sorun yaratıyor. Bu ortamın bir an önce denetim altına alınarak haber hırsızlı̆̆ının önüne geçilmesi gerekiyor." demiştir (Aksakal, 2017). Pusula yöneticisi özellikle ulusal basına yansıyacak haberler ürettiklerinde birçok internet gazetesinin kendi sitelerini kaynak göstermeden haberlerinin birebir alındığını belirtmiştir (Tekin, 2017). Ayrıca haberlerin okuyucuya hızlıca ulaştırılması esnasında ortaya çıkan imla yanlışlıklarına dikkat çeken yöneticiler, muhabirlerin bu konuda daha donanımlı hale gelmeleri gerektiğini vurgulamışlardır. Yöneticiler dil bilgisinin, yazım kurallarının doğru kullanılmasının gazete haberlerinin kalitesini göstermeleri bakımından en önemli unsur olduğunun altını çizmiştir (Tekin vd., 2017).

Yöneticiler internet gazeteciliğinde hılı olma zorunluluğunun haber kaynakları ile etkileşim esnasında sorunlar yarattığını haberlerin doğruluğunda ise en önemli yardımcılarının vatandaşlar olduğunu dile getirmişlerdir. Pusula yöneticisi hızlı haber hazırlama adına bazen bir haberin doğruluğundan emin olunmasa da sitede yayınlayabildiklerine bu noktada haberlerini takip eden okuyuculardan dönüş aldıklarına vurgu yapmıştır (Tekin, 2017). Milletin Sesi yöneticisi, zaman zaman ekonomi haberlerinde verdikleri rakamlarda sorunlar olabildiğini ifade etmiş okuyucuların kendilerini arayarak doğru bilgiyi gazeteye ulaştırdıklarını dile getirmiştir (Aksakal, 2017).

Milletin Sesi yöneticisi dijital gazeteciliğin gazetecilik mesleğini öldürdüğüne de dikkat çekerken; yazdığı haberin kendisine ait olduğunu dahi kanttlayamaz hale geldiklerini ifade etmiştir (Aksakal, 2017). Güne Bakış yöneticisi, gazetecilik mesleğinin internet gazeteleri sayesinde eski saygınlığının kalmadığını ifade etmiş, gazetecilerin de artık haber yazmak için haber peşinde koşmadığını dile getirmiştir. Herkesin birbirinde haber aldığını, copy-paste gazeteciliğinin dijital gazeteler sayesinde yaygınlaştığını vurgulamıştır. Sadece Erzurum'da değil dünyanın herhangi bir yerinde internet gazeteciliği yapmak isteyenlerin, oturduğu yerden haber yapmak yerine daha çok araştırma yapması gerektiğine vurgu yapan yönetici, gazetecinin hazırladığ 1 haberlerin, dijital gazeteler sayesinde mekânsal sınırları aştığını, dolayısıyla bu mesleğin ufkunun genişlediğini ifade etmiştir (Akdağ, 2017).

İnternet gazeteleri sayesinde haber kaynakları ile aynı mekânda bulunma zorunluluğunun ortadan kalktığını dile getiren Milletin Sesi yöneticisi, internet sayesinde mail, e- 
posta gibi yöntemlerle haber kaynaklarıyla iletişim kurduklarını ifade etmiş bu sayede muhabirlerinin kısa sürede birden fazla haber ürettiğinin altını çizmiştir (Aksakal, 2017). Pusula yöneticisi zaman zaman okurların kaydettikleri görüntüleri ya da fotoğrafları kendilerine ilettiğini belirtmiş bu sayede haber çeşitliliklerinin bazı günler arttığına dikkat çekmiştir. Yönetici, vatandaştan gelen haberlerin gazetelerinde yer almasiyla birlikte gazete ve vatandaş arasında sıkı bağların kurulduğuna vurgu yapmıştır (Tekin, 2017).

İnternet ortamının soğukluğuna vurgu yapan Pusula yöneticisi, haber kaynakları ile yüz yüze görüştüklerinde habere ilişkin daha kapsamlı bilgiler elde ettiğini hatta haberin ilerleyen günlerde hangi aşamaya geldiğini dahi kaynağın kendisini arayarak anlattığını ifade etmiştir. İnternet gazeteciliğinin sıcak insan ilişkilerini yok ettiğini ifade eden yönetici; haber kaynaklarının dijital ortamda zaman zaman kendilerine güven duymakta zorlandığını dile getirmiştir. Dijital gazeteciliğin iş olanaklarını kimi yerde olumlu kimi yerde olumsuz etkilediğine dikkat çeken yönetici, geçmiş dönemlerde gazeteler habere hem muhabir hem fotoğrafçı yollarken, bugün tek muhabirin tüm işi yapabilir hale geldiğini ifade etmiş, internet ortamı sayesinde haberlerin video haline getirilerek okuyucuya ulaştırılabilir olduğunun altını çizmiştir. Her bir uzmanlık için ayrı ayrı çalışan istihdam etmek zorunda kalan gazete patronlarının artık tek bir muhabir ile dahi gazete çıkarabilir hale geldiğine dikkat çeken yönetici, dijital ortamın kendi gazetelerinde bir istihdam yaratmadığını ifade etmiştir (Tekin, 2017).

Milletin Sesi yöneticisi, yaşanılan çağ koşullarında ayakta kalabilmenin yollarından birinin yeni iletişim teknolojilerine hâkim olmaktan geçtiğine dikkat çekerken, istihdam ettikleri ve etmeyi planladıkları tüm çalışanlarının dijital teknolojiye hâkim olmaları gerektiğini dile getirmiştir. Yönetici internet gazeteciliğinin istihdam anlamında Erzurum'da bir değişiklik yaratmadığını vurgulamış, herhangi bir gazetede çalışan muhabirin kendi internet gazetesinin de olduğunu ifade etmiştir. Mevcut muhabirlerinden birinin özellikle internet gazetesini güncelleme işi ile sorumlu tutulduğunu ifade eden yönetici, bu alan için yeni bir çalışan istihdam edecek maddi güçlerinin olmadığını dile getirmiştir (Aksakal, 2017). Güne Bakış yöneticisi ise dijital gazeteleri için bir personel istihdam ettiklerini bu personelin internet gazetesinin yanı sıra basılı gazete için de haber ürettiğinin altını çizmiştir (Akdağ, 2017).

Pusula yöneticisi zaman zaman okurların kaydettikleri görüntüleri ya da fotoğrafları kendilerine ilettiğini belirtmiş bu sayede haber çeşitliliklerinin bazı günler arttığına dikkat çekmiştir. Yönetici vatandaştan gelen haberlerin gazetelerinde yer almasıyla birlikte gazete ve vatandaş arasında sıkı bağların kurulduğuna vurgu yapmıştır. Haberin hızlıca yayılmasından dolayı çalışanlarının iyi Türkçe bilgisine sahip olması gerektiğini ifade eden yönetici; dil bilgisinin, yazım kurallarının doğru kullanılmasının gazete haberlerinin kalitesini göstermeleri bakımından en önemli unsurlar olduğunun altını çizmiştir (Tekin, 2017). Dijital gazeteler sayesinde gazetelerin sağlam arşivlerinin oluştuğuna dikkat çeken Milletin Sesi yöneticisi, basılı gazetelerde olduğu gibi geçmiş dönemlere ilişkin bir habere ulaşmakta kargaşa yaşanmadığını ifade etmiş, haberlerin sağlıklı ortamda saklandığına vurgu yapmıştır (Aksakal, 2017). Güne Bakış yöneticisi de internet gazeteleri sayesinde büyük bir haber arşivlerinin olduğunu ifade etmiş, bu sayede istedikleri an istedikleri habere ilișkin geçmiş dönemlerde yazılan haberlere ulaştıklarını dile getirmiştir (Akdağ, 2017).

Milletin Sesi yöneticisi internet ortamının kontrol altına alınması gerektiğini vurgulayarak, herkesin internet gazetesi yayınlayabildiğine şaşkınlıkla baktığını belirtmiş, internet gazetesi yayınlayabilmek için bir takım kriterler olması gerektiğini ifade etmiştir. $\mathrm{Bu}$ bağlamda en önemli ve bağlayıcı kriterin sarı basın kartı olduğuna vurgu yapmıştır. Sarı basın kartı sahibi olmayan kimselerin internet gazetesi yayınlamasına izin verilmemesi gerektiğine dikkat çeken yönetici bu sayede dijital gazeteciliğin bilgili kişilerce yapılacağına ve gazetecilik mesleğinin saygınlığının sürdürüleceğine dikkat çekmiştir (Aksakal, 2017).

Pusula yöneticisi, dijital gazeteciliğin herkese ulaşabilmesi açısından büyük bir nimet olduğunu ifade etmiş fakat bu esnada dijital gazetelerin kalitesinin düştüğünü vurgulamıştır. Bu ortamda gazetecilik yapmak için masraf edilmemesinin, akıllı telefon sahibi birçok kişinin internet gazetesi kurmasına neden olduğunu dile getirmiştir. $\mathrm{Bu}$ konuda Basın İlan Kurumu'nun düzenleme getirmesi gerektiğine vurgu yapan sorumlu, teknolojinin geleneksel gazeteciliği olumsuz etkilediğini ifade etmiştir (Tekin, 2017).

Tablo 7. Dijital Gazeteciliğe Tamamen Geçiş Fikrine İlişkin Veriler

\begin{tabular}{lccc}
\hline Gazetenin Ad1 & Evet & Hayır & Belirsiz \\
\hline Pusula & - & + & - \\
Milletin Sesi & - & + & - \\
Güne Bakış & - & + & - \\
\hline
\end{tabular}

Yukarıdaki tabloda gazetelerin gelecekte sadece internet ortamında yayınlanıp, yayınlanamayacağına ilişkin yöneticilerin düşüncelerini içeren bilgiler yer almaktadır. Gazete yöneticileri genel olarak dijital gazeteciliğin basılı gazeteciliği yok edemeyeceği düşüncesini savunurken dijital gazetecilikte birlikte basılı gazetecilik türünün sürdürüleceği görüşünü savunmaktadır. Yöneticiler dijital gazeteler için hukuki bir kontrol mekanizması kurulması gerektiğini de dile getirerek bu alanın hukuki sorumluluklarının sınırlarının kesin olarak çizilmemesinin; vergisini veren, çalışanlarına sigorta yapan, hukuki düzenlenmelere uyan gazete sahiplerinin mağdur olmasına neden olduğunu ifade etmektedirler (Tekin vd., 2017).

\section{Sonuç}

$\mathrm{Bu}$ çalışmada yeni iletişim teknolojilerinin yerel medyada ortaya çıkardığı dönüşümler avantajlar ve dezavantajlar üzerinden Erzurum yerel basını örnekleminde incelenmiștir. Basın İlan Kurumu'nun vasıflı gazete kabul ettiği ve dijital gazetesini sürekli güncelleyen 4 gazete örnekleminden yola çıkılarak; dijital yerel gazetelerin yerelliğe bakış açıları, yerelliği nasıl konumlandırdıkları, dijital gazetelerin avantaj ve dezavantajları tartışılmıştır. Erzurum'da meydana gelen bir olayın sadece Erzurum'da yankı bulmadığı internet teknolojisinin olduğu her yerden duyulduğu, yerel haberciliğin dijitalleşme sayesinde coğrafi sınırları aştığı tespit edilmiştir.

Dijital gazetecilikte hızlıca yazılan ve yayılan haberler dünyanın çeşitli yerlerine ulaşmakta fakat bu hız unsuru nedeniyle gazetelerde çeşitli imla hataları, doğruluğundan 
emin olunmayan haber başlıkları görülmektedir. $\mathrm{Bu}$ bağlamda Erzurum yerel gazete yöneticileri teknolojiye hâkim personeller istihdam etmenin doğru olacağını ve bu sayede haberlerin hiz unsuruna kurban edilmeyeceğini vurgulamaktadır. Fakat Erzurum yerel basinı bu noktada gerekli girişimler sağlayamamaktadır. Dijital gazeteciliğin geniş bir arşiv olanağı sunması gazetecilik pratikleri bakımından önemli bir avantaj iken, bu arşive hâkim olabilecek personelin donanımlı olması beklenmektedir. Yapılan görüşmelerde dijital gazeteciliğin Erzurum'a yerel basın bağlamında yeni bir istihdam olanağı sağlamaması bu noktada yine önemli soru işareti yaratmakta, dijital gazeteciliğin gerektirdiği vasıflara sahip personellerin gazetelerde "internet editörü" olarak istihdam edilmesi gerekmektedir.

Dijital gazeteciliğin tam anlamıyla hukuki denetime tabi olmaması Erzurum yerel basını için önemli bir dezavantaj olmakta, sektöre hâkim olan gazetelerin ve gazetecilerin haksızlığa uğramasına neden olmaktadır. Yapılan görüşmelerde yöneticiler, kendileri tarafından yazılan haberlerin dahi artı kendilerine ait olduğunu kanıtlayamayacak hale geldiklerini vurgulamaktadırlar. Ayrıca dijital gazetecilik için bir nebze de olsa yatırım yapan yerel gazeteler, hukuki denetim olmadığından her geçen gün sayısı artan internet gazetelerinin bu işi neredeyse ücretsiz ve reklam amaçlı yaptığını ifade etmekte, bu durumun da Erzurum yerel basınının kalitesinin düşmesine neden olabileceğinden endişe etmektedirler.

Yapılan görüşmelerde gazete yöneticileri ağırlıklı olarak dijital gazeteciliğin dezavantajlarını dile getirmiş, yine bu dezavantajlardan biri olan tiraj düşüklüğünü vurgulamışlardır. İnternet gazeteleri nedeniyle tiraj kaybı yaşadıklarını ifade eden yöneticiler, Erzurum yerel basının ayakta kalması için, Erzurumlu vatandaşlardan destek istemekte, basılı gazetelerini satabilmenin kendilerine ciddi manada getirisi olmasa da gazetecilik mesleğinin hala yapılıyor olması açısından moral verdiğine dikkat çekmektedirler.

Sonuç olarak dijital gazetecilik Erzurum'da basılı gazeteciliği zora soktuğundan dezavantaj olarak görülmekte; fakat bu gazetecilik türünün sınırları aşmasından dolayı herkese ulaşabilmesi yerel gazeteleri memnun etmektedir. $\mathrm{Bu}$ kapsamda gazetelerin dijital gazeteciliğin avantajlarına yoğunlaşması daha doğru olacaktır çünkü çevrimiçi ortamda güçlü yayıncılık yapan bir yerel gazete, eski zamanlarda sınırlı olan coğrafyanın dezavantajlarını ancak internet teknolojisiyle firsata çevirecektir. Gazeteler basılı gazetelerin içeriğini birebir dijital ortama aktarmak yerine profesyonel formatlar geliştirerek özgün içeriklerle daha çok okuyucuyu sitelerine çekebileceklerdir. Ayrıca yerel gazetelerin iletişim fakültesi mezunlarını istihdam etmeleri, gazetelerde yayınlanan haberlerin daha anlaşılır ve hatasız yayınlanmasına katkı sağlayacaktır.

\section{Kaynakça}

Akdağ, M. (2017). Günebakış Gazetesi Genel Yayın Yönetmeni ve Yazı İşleri Müdürü ile 16 Ağustos 2017 tarihinde yapılan görüşme. Erzurum.

Aksakal, M.H. (2017). Milletin Sesi Gazetesi Haber Müdürü ile 15 Ağustos 2017 tarihinde yapılan görüşme. Erzurum.
Alankuş, S. (2003). BİA ve BİA Eğitim Çalışmaları Üzerine. İçinde: Medya ve Toplum, Haz. Sevda Alankuş. İstanbul: IPS İletişim Vakfı Yayınları.

Alyanak, K. (1999). Erzurum'da Basın. Erzurum: Erzurum Tarihini Araştırma ve Tanıtma Derneği Yayınları.

Aziz, A. (2014). Sosyal Bilimlerde Araştırma Yöntemleri ve Teknikleri. Ankara: Nobel Yayınları.

Castells, M. (2000). Grass rooting the space of flows. In: J. Wheeler, Y. Aoyama \& B. Warf (Eds.), Cities in the Telecommunications Age: The Fracturing of Geographies (s. 18-30). New York: Routledge.

Çakır, H. (2007). Geleneksel Gazetecilik Karşısında İnternet Gazeteciliği. Erciyes Üniversitesi Sosyal Bilimler Enstitüsü Dergisi, 22.

Çelik, T. (2005). Bilişim Çağında Gazetecilerin Internet ve Teknolojiyi Kullanım Düzeyi: Karşılaştırmalı Bir Değerlendirme. Yüksek Lisans Tezi. İzmir: Ege Üniversitesi.

Çoban, S. (2006). Illetişim Fakültesi Öğrencilerinin Internet Haberciliğinin Güvenilirliğine İlişkin Tutumlarl: Ístanbul, Ankara ve İzmir Illerini Kapsayan Bir Uygulama Örneği. Yüksek Lisans Tezi. Eskişehir: Anadolu Üniversitesi.

Dijk. J. V. (2016). A ̆ toplumu. (çev: Özlem Sakin). İstanbul: Kafka Epsilon Yayıncılık.

Erinç, O. (2007). Yerel Medyanın Tarihsel Gelişimi ve Geleceği. İçinde: Türkiye'de Yerel Basın. (Haz. Suat Gezgin). İstanbul: İstanbul Üniversitesi İletişim Fakültesi Yayınları.

Gezgin, S. (2002). Geleneksel Basın ve İnternet Gazeteciliği. İçinde: Internet Çă̆ında Basın. (Haz: Serhan Yedig), Haşim Akman. İstanbul: Metis Yayınları.

Gezgin, S. (2007). Türkiye'de Yerel Basın. (Haz: Suat Gezgin). İstanbul: İstanbul Üniversitesi, İletişim Fakültesi Yayınları.

Girgin, A. (2001). Türk Basın Tarihi'nde Yerel Gazetecilik. İstanbul: İnk1lap Kitabevi.

Güz, N. (1997). Yerel Basında Gazetecinin Tanımı, İşlevi, Çalışma Koşulları ve Sorunları. İçinde: Yerel Basın Eğitim Seminerleri Dizisi. No:1. İstanbul: Erdini Basımevi.

Habermas, J. (1984). The Theory of Communicative Action: Vol. 1. Reason and the Rationalization of Society (çev: Thomas McCarthy). Boston: Beacon Press. (Erişim : 15.11.2017),

http://www.tuik.gov.tr/PreHaberBultenleri.do?id=24673

Işık, M. (2014). Ocak 2012 Gazete Birleşmelerinin Erzurum Basının Gelişim Süreci İçerisindeki Yeri ve Önemi. Ístanbul Üniversitesi İletişim Fakültesi Dergisi, 51-74.

İnuğur, M. N. (2005). Basın ve Yayın Tarihi. İstanbul: Der Yayınları.

Kara, H. (2005). Bilgisayar-İnternet Teknolojisi ve Değișen Gazetecilik. İçinde: Yeni İletişim Teknolojileri ve Medya, (Haz: Sevda Alankuş). İstanbul: IPS Yayınları. 
Karaduman, M. (2005). İnternet ve Gazetecilik. İçinde: Yeni Iletişim Teknolojileri ve Medya, (Haz: Sevda Alankuş). İstanbul: IPS Yayınları.

Karasar, N. (1991). Bilimsel Araştırma Yöntemi: Kavramlar, Ilkeler, Teknikler. Ankara: Sanem Yayıncılık.

Öztürk, Y. (1992). Yerel Anadolu Basını. Yerel Basin Kurultayl Bildiriler. Adana: Çukurova Gazeteciler Cemiyeti Yayınları.

Pavlik, J. V. (2013). Yeni Medya ve Gazetecilik. (çev. Müge Demir \& Berrin Kalsın). Ankara: Phoenix Yayınevi.

Perin, C. (1974). Tarih Boyunca Düşünce ve Basın Özgürlüğ̈̈. Ankara: Remzi Kitabevi.

Stevenson, N. (2008). Medya Kültürleri. Ankara: Ütopya Yayınları.

Şeker, M. (2007). Tekniği, İçeriğii, Çalışan Profili, Haber Kaynakları, Ekonomi Politiği, Gücü ve Sorunlartyla Yerel Gazeteler. Konya: Tablet Yayınları.

Tekin, S. (2017). Pusula Gazetesi Genel Yayın Yönetmeni ile 15 Ağustos 2017 tarihinde yapılan görüşme. Erzurum.

Topuz, H. (1973). 100 Soruda Türk Basin Tarihi. İstanbul: Gerçek Yayınevi.

Toruk, İ. (2008). Gutenberg'den Dijital Çağa Gazetecilik. İstanbul: Literatürk Yayınları.

Ünal, Ş. (1996). Yerel Basın ve Sorunları. Yeni Türkiye Dergisi, 12, 1068- 1072.

Vural, A. M. (1999). Yerel Basın ve Kaтиoyu. Eskişehir: Anadolu Üniversitesi Yayınları.

Wimmer, D. D., \& Dominick, J. R. (2000). Mass Media Research: An Indroduction. Belmont: Wadsworth Publishing Company.

Yolcu, Ö. I. (2007). Yerel Gazetelerin İnternet ortamındaki Görünümü. İçinde: Türkiye'de Yerel Basın, (Haz: Suat Gezgin). İstanbul: İstanbul Üniversitesi İletişim Fakültesi Yayınları. 